\title{
Renascent entrepreneurship
}

\section{Erik Stam • David Audretsch • Joris Meijaard}

\begin{abstract}
Why should individuals who have exited their firm consider re-entering into entrepreneurship, i.e. become renascent entrepreneurs? According to the logic of economic models of firm dynamics there is no reason to re-enter into entrepreneurship following firm failure. In contrast, research on nascent entrepreneurship has shown the positive effect of entrepreneurial experience on planning a new firm start. Based on empirical evidence from a database consisting of ex-entrepreneurs, this study shows that renascent entrepreneurship is a pervasive phenomenon. Next to passive learning, active learning plays an important role in the explanation of entrepreneurial preferences subsequent to firm exit. This study provides new insights into the role of prior knowledge and firm exit in the entrepreneurial process.
\end{abstract}

Keywords Renascent entrepreneurs · Nascent entrepreneurs · Firm exit · Entrepreneurial experience

JEL Classification $\mathrm{J} 24 \cdot \mathrm{L} 26 \cdot \mathrm{M} 13$

E. Stam

Centre for Technology Management, University of Cambridge, Cambridge, UK

E. Stam $(\bowtie)$

Urban and Regional research centre Utrecht (URU), Faculty of Geosciences, Utrecht University, P.O. Box 80115, 3508 TC Utrecht, The Netherlands

e-mail: e.stam@geo.uu.nl

E. Stam • D. Audretsch

Max Planck Institute of Economics - Entrepreneurship, Growth and Public Policy Group, Jena, Germany

D. Audretsch

Institute for Development Strategies, Indiana University, Bloomington, IN, USA

J. Meijaard

EIM Business \& Policy Research, Zoetermeer, The Netherlands

J. Meijaard

RSM Erasmus University, Rotterdam, The Netherlands 


\section{Introduction}

Promoting entrepreneurship has become a key instrument of policies for economic growth and employment creation. A focal point of such entrepreneurship policies is to increase the share of the labor force that would be potentially interested in entering into entrepreneurship. This preference for entrepreneurship is said to be hampered, especially in Europe, by the stigma on failure (European Commission 2002). Many people may be uncertain about their entrepreneurial skills, and this uncertainty becomes more constraining when a failed start-up is highly stigmatized.

Many scholars have focused on the uncertainty involved in entrepreneurial activity that deters entrepreneurship. In the logic of the Jovanovic (1982) and Lippman and Rumelt (1982) models of firm dynamics, individuals are uncertain about their actual entrepreneurial abilities. They can only learn about their actual entrepreneurial abilities through the process of starting a new firm. Only by starting a new firm and observing the subsequent performance a nascent entrepreneur is able to learn about her endowment of entrepreneurial talent. The firms of entrepreneurs with inferior skills ultimately exit. Thus, an important implication of these models of entrepreneurship is that a positive entrepreneurial performance subsequent to startup will lead the entrepreneur to infer that she has a strong endowment of entrepreneurial skills, which will lead her to persist as an entrepreneur. By contrast, those startups with a poor performance will lead entrepreneurs to infer that they have only a poor endowment of entrepreneurial skills and they will tend to exit out of entrepreneurship. Thus, the nascent entrepreneur can only learn about her true but unobservable underlying endowment of entrepreneurial skills by inferences gleamed from the actual entrepreneurial performance. Those entrepreneurs learning from actual entrepreneurial experience that they have only poor endowments of entrepreneurial skills select themselves out of entrepreneurship, while those learning that they have rich endowments of entrepreneurial skills remain in entrepreneurship.

A second important implication of these models of firm dynamics is that once an individual has learned that she has a paucity of entrepreneurial skills, there is no reason to subsequently (again) become a nascent entrepreneur. According to these models, the (lack of) underlying entrepreneurial skills would already have been revealed through the entrepreneurial experience. Thus, there would be little incentive to (re-)enter into entrepreneurship, or what we term here as renascent entrepreneurship.

However, a number of empirical studies have consistently found a positive effect of entrepreneurial experience on the preference to start again as a business owner. If such ex-entrepreneurs had already learned that they did not possess a strong endowment of entrepreneurial skills, why would they re-enter into entrepreneurship? The purpose of this paper is to resolve this empirical paradox and to challenge both the passive view of entrepreneurial learning along with the high propensity for renascent entrepreneurship.

In the second section of this paper we present a model of entrepreneurship. The third section presents a review of empirical studies on nascent entrepreneurship. Next, the research method and data are described. In the fifth section logistic regression models are used to explain why some ex-entrepreneurs become renascent entrepreneurs, while others abstain from renascent entrepreneurship. In the final section the findings are discussed and conclusions are presented. In particular, we 
Fig. 1 Entrepreneurial performance over time

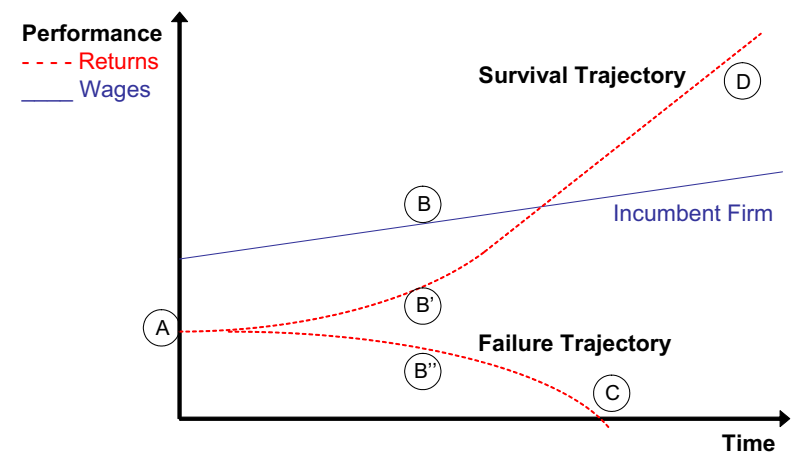

find that the propensity for ex-entrepreneurs to become renascent entrepreneurs is not homogenous, but rather systematically related to the capacity to absorb knowledge and learn from previous entrepreneurial experience.

\section{A model of entrepreneurship}

The links between nascent entrepreneurship and entrepreneurial performance are depicted in Fig. 1. As the literature has documented (Parker 2004, 2005), the average return accruing from starting a new firm, at point $\mathrm{A}$, lies below the wage that could be earned working in an incumbent firm. However, the performance gap between the returns to entrepreneurship and wages earned working in an incumbent firm does not remain constant over time, but may increase or decrease. While the entrepreneurial decision occurs within a relatively narrow lapse of time, the entrepreneurial process involves the evolution of the new firm from birth towards maturity and firm exit. The entrepreneurial process may result in a return far exceeding that expected from wages earned in an incumbent firm, as depicted by point D, or alternatively, in a return far below the benchmark wages, at point C. Thus, as Knight (1921) pointed out, the entrepreneurial process is shrouded in uncertainty.

Figure 1 suggests that entrepreneurial performance outcomes are inherently uncertain. They may result in outcomes like C or D (Audretsch et al. 2006). Once an individual has attained point $\mathrm{C}$, she is confronted with the decision of re-entering into entrepreneurship, again at point $\mathrm{A}$ (i.e. renascent entrepreneurship). ${ }^{1}$ We expect that the entrepreneurial experience is of little value for the wage earned at an incumbent, ${ }^{2}$ and thus does not affect the wage level (curve) after firm exit.

Within the economics literature, the prevalent theoretical framework has been the general model of income choice. This has been at times referred to as the model of entrepreneurial choice (Evans and Jovanovic 1989; Parker 1996). The model of

\footnotetext{
${ }^{1}$ The successful entrepreneur at point D may also choose to sell his firm and to start again at point A. See the case studies on serial entrepreneurship by Wright et al. (1997).

${ }^{2}$ Depending on the institutional context one could expect a positive effect of entrepreneurial experience in countries with an entrepreneurial culture, and a negative effect in countries where entrepreneurial 'failure' is stigmatized. Bruce and Schuetze (2004) found evidence for the latter effect: individuals with entrepreneurial experience have difficulty returning to the wage sector.
} 
income or entrepreneurial choice dates back at least to Knight (1921), but was more recently extended and updated by Holmes and Schmitz (1990) and Jovanovic (1994). In its most basic rendition, individuals are confronted with a choice of earning their income either from wages earned through employment in an incumbent firm or else from profits accrued by starting a new firm. The essence of the model of entrepreneurial choice is to compare the wage an individual expects to earn through employment, W, with the profits expected to accrue from a new-firm startup, $\mathrm{P}^{*}$. The probability of starting a new firm, $\mathrm{P}(\mathrm{s})$, can be represented as:

$$
\mathrm{P}(\mathrm{s})=\mathrm{f}\left(\mathrm{P}^{*}-\mathrm{W}\right)
$$

According to the Jovanovic (1982) and Ericson and Pakes (1995) theories of firm dynamics and selection, entrepreneurs may start a new firm at a small, even suboptimal, scale of output, and then, if merited by subsequent performance, expand as depicted by the evolution from point A to D. The firms of entrepreneurs that observe a positive performance, as reflected by $\mathrm{P}^{*}$, will grow, whereas those that are not successful will remain small and may ultimately be forced to exit out of entrepreneurship.

An important implication is that if an entrepreneur infers from a positive performance that she has an underlying high endowment of entrepreneurial skills, she will continue with entrepreneurship. By contrast, if she infers from a poor performance that she has an impoverished endowment of entrepreneurial skills, she would revise $\mathrm{P}^{*}$ downward. This would make exit out of entrepreneurship more likely, as working for an incumbent firm with wage $\mathrm{W}$ is becoming more attractive. In the Jovanovic (1982) theory of passive learning, $\mathrm{P}^{*}$ is likely to be revised downward just before firm exit, and there is no reason that $\mathrm{P}^{*}$ would increase later.

By contrast, we test whether $\mathrm{P}^{*}$ can actually increase as a result of entrepreneurial experience. If the entrepreneur learns not just about the original endowment of entrepreneurial skills, but also how to augment these original entrepreneurial skills, then $\mathrm{P}^{*}$ will not remain invariant to the entrepreneurial experience, but will actually be higher as a result of the entrepreneurial experience. In contrast to the original Jovanovic (1982) theory, this second type of learning would suggest that exentrepreneurs would indeed contemplate re-entering into entrepreneurship, becoming renascent entrepreneurs. Evidence of the latter suggestion would reject the hypothesis that ex-entrepreneurs lose their entrepreneurial preferences.

\section{Literature review on nascent entrepreneurship}

In the last decade a number of studies on the characteristics of individuals that aspire or take steps to start a business have been undertaken. In this section we summarize the main findings in the literature linking characteristics of individuals to the propensity to undertake entrepreneurial actions. ${ }^{3}$ One of the most relevant findings here is the positive effect of prior entrepreneurial experience on subsequent entrepreneurial preferences. To some extent, the relationship between personal

\footnotetext{
${ }^{3}$ See also Davidsson (2006) for a review of empirical studies on nascent entrepreneurship. 
characteristics and renascent entrepreneurship may also be similar to that with nascent entrepreneurship. We will discuss the general findings in the literature on nascent entrepreneurship in this section.

\subsection{Human capital}

There is a long research tradition linking the role of human capital to entrepreneurship. Studies have typically found a positive relationship between general human capital and nascent entrepreneurship (Van Gelderen 1999; Diochon et al. 2002; Kim et al. 2006; Reynolds et al. 2004; Wagner 2005). Individuals with more education may be more willing to start a new firm because they can relatively easily find a job if the venture fails. Wagner (2005) also found evidence for Lazear's (2004) "jack-of-all-trades" theory of entrepreneurship, with a positive effect of the number of fields of experience on nascent entrepreneurship.

Prior industry experience - a factor that has a clear negative effect on firm exit (cf. Klepper 2002; Phillips 2002) - is not found to have an effect on nascent entrepreneurship. It is likely that prior industry experience will only have a positive effect when the intended new business will be active in an industry that is related to this experience.

Perhaps the most relevant experience of individuals aspiring to start a business is entrepreneurial experience. In this respect, Kolvereid and Isaksen (2006) and Tamasy (2006) found a positive effect of entrepreneurial experience (i.e. having had a business before) on entrepreneurial intentions. This is quite in contrast to the logic of economic models of firm dynamics, assuming that the ex-entrepreneurs had to close their unsuccessful business. An escape from this logic would be the 'exit' of a successful business, via a merger or acquisition (at point D in Fig. 1). A more contrasting explanation may be that these ex-entrepreneurs have not only learned passively whether they had the necessary entrepreneurial skills, but they also learned actively to develop or augment their entrepreneurial skills, perhaps not sufficient to successfully run their prior business, but well enough to engage in future entrepreneurial efforts. ${ }^{4}$ Tamasy (2006) indeed found a positive relation between having been self-employed and having the knowledge and skills to start a business.

How would human capital impact renascent entrepreneurship? On the one hand, it raises $\mathrm{W}$, or the opportunities available to ex-entrepreneurs in working for incumbent organizations. On the other hand, a higher level of human capital may provide the ex-entrepreneur with the absorptive capacity to learn from the entrepreneurial experience and augment the initial endowment of entrepreneurial skills. The latter suggests a positive relationship between human capital and the propensity for exentrepreneurs to become renascent entrepreneurs.

\footnotetext{
${ }^{4}$ There might be a self-reinforcing effect, that however does take some time to develop (perhaps extending over the life course of the first business): improved entrepreneurial skills positively affect the recognition of entrepreneurial opportunities (cf. Ronstadt 1988), while the pursuit of new opportunities improves the entrepreneurial skills in a trial-and-error process.
} 


\subsection{Financial capital}

A series of studies (Evans and Leighton 1989; Evans and Jovanovic 1989; Blanchflower and Oswald 1998) has identified that a lack of financial resources constrains new and small firms. The theory of liquidity constraints assumes that a major concern of nascent entrepreneurs is obtaining finance, which would imply that the receipt of capital (e.g. via an inheritance or gift) increases an individual's likelihood of becoming self-employed, both through the direct supply of capital and through the increased likelihood of bankers providing capital (due to the larger collateral available). However, research on nascent entrepreneurship has shown mixed evidence and has generally found no effects of household wealth and income (Kim et al. 2006) but a positive effect of individual income (Van Gelderen 1999).

\subsection{Social capital}

Recent research also suggests that social capital may impact entrepreneurship, and nascent entrepreneurship in particular (Davidsson and Honig 2003; Arenius and De Clercq 2005). Davidsson and Honig (2003) have argued that individuals who come from families that own businesses (bonding social capital), or from community networks owning or encouraging self-employment (bridging social capital), will utilize their social capital resulting in more successful discovery activities (i.e. nascent entrepreneurship) than by those who do not have this social capital. Davidsson and Honig (2003) and Wagner (2005) found a positive effect of having entrepreneurial family and friends, i.e. entrepreneurial role models, on nascent entrepreneurship, while Kim et al. (2006) did not find any effect.

On the one hand social capital may provide a mechanism for absorbing entrepreneurial experience and the augmentation of entrepreneurial skills. This would suggest a positive relationship between social capital and the likelihood of exentrepreneurs to become renascent men. On the other hand, the entrepreneurial experience gained during the career of the ex-entrepreneur might become a substitute for entrepreneurial social capital. Entrepreneurial social capital might also have normative effects, as ex-entrepreneurs who are active in a social environment with many entrepreneurs will feel peer-pressure to start again.

\subsection{Demographics}

Nascent entrepreneurship tends to decline with age. In an international study, Blanchflower et al. (2001) found that the probability of preferring to be selfemployed is strongly decreasing with age. A negative effect of age on nascent entrepreneurship was also found in several country studies (Van Gelderen 1999; Diochon et al. 2002; Reynolds et al. 2004). A common interpretation of this consistent finding is that younger individuals may be more adventurous (maybe overconfident: Forbes 2005). As a result, they are more likely to have entrepreneurial preferences. The incentives of an individual to start a new firm decrease over time, as her expectation of the sum of future payments out of entrepreneurship declines (Lévesque and Minniti 2006). 
A consistent empirical result from the literature on nascent entrepreneurship is also that gender matters. Women exhibit a consistently lower likelihood of becoming a nascent entrepreneur than their male counterparts (Van Gelderen 1999; Diochon et al. 2002; Reynolds et al. 2004; Wagner 2005).

Only a few studies focusing on nascent entrepreneurship have taken into account the geographic location of individuals. The limited evidence to date indicates that people in urban locations are more likely to become a nascent entrepreneur than their rural counterparts (Van Gelderen 1999; Wagner and Sternberg 2004; Arenius and De Clercq 2005; Kolvereid and Isaksen 2006). Due to the density of people and organizations, urban and especially metropolitan locations provide more entrepreneurial opportunities than rural locations (Jacobs 1961).

\subsection{Firm exit type}

Research has identified a diversity in types of exits: (1) voluntary exits to acquire a better job (Van Praag 2003; Bates 2005), (2) exits due to personal circumstances, (3) exits by way of successfully selling the firm (Headd 2003), and (4) bankruptcy (Thornhill and Amit 2003). It is likely that the type of exit and also the timing of exit - either in the "valley of death" (within 3 years after start-up) or later on - affect the entrepreneurial preferences subsequent to firm exit.

A successful sale of the prior firm is likely to deliver financial resources that can be used as starting capital for a restart, while bankruptcy is likely to lead to financial constraints, lowering the feasibility of a restart. To a certain extent, the effects of these types of exit on entrepreneurial preferences can be interpreted with the theory of liquidity constraints. We assume that the receipt of capital due to the sale of (parts of) the prior firm has a positive effect on the preferences to start a new firm again. In line with this argument, we expect that entrepreneurs whose firm was closed due to bankruptcy are relatively resource constrained (they are likely to have debts, and have problems with getting bank loans in the near future). As a consequence, they are less likely to start again. Research by Van der Klauw (1998) also revealed the opposite effect: entrepreneurs that went bankrupt were more likely to have entrepreneurial preferences. The study by Van der Klauw (1998) also revealed that entrepreneurs that stopped because of personal reasons were less likely to have entrepreneurial preferences later on.

Concerning the timing of the exit, it may be inferred that entrepreneurs whose previous firm has survived the valley of death, have a strong belief that they possess a relatively strong endowment of entrepreneurial skills. This would suggest that they might have a higher propensity to become renascent entrepreneurs.

\subsection{Hypotheses}

Three basic hypotheses can be formulated based on the existing literature. Firstly, entrepreneurs that have had an unsuccessful firm are less likely to aspire to start a firm again because they have found out that they do not have sufficient entrepreneurial skills.

Hypothesis 1 Entrepreneurs who exited an unsuccessful firm will not aspire to reenter into entrepreneurship. 
Second, entrepreneurs that have had a (once) successful firm are more likely to aspire to start a firm again. They have found out that they have sufficient entrepreneurial skills. These entrepreneurs may have discovered that they have particular skills to 'build' new firms, but not to manage growing, large firms (cf. Holmes and Schmitz 1990). In addition, they might have sold their firm, which eases the liquidity constraints for the start of a subsequent firm.

Hypothesis 2 Entrepreneurs who exited a once successful firm are likely to aspire to re-enter into entrepreneurship.

Third, entrepreneurs that have improved their entrepreneurial skills during a prior spell of entrepreneurship are likely to intend to start a firm again, because the expected value of future returns on entrepreneurship has increased, while it has not increased expected wage income. The active entrepreneurial learning might not always be applied instantaneously in order to improve the performance of the firm. If, for some reason (market or personal circumstances), the entrepreneurs have to exit, they might still use their improved skills to start subsequent firms in other future circumstances.

Hypothesis 3 Entrepreneurs that have improved their entrepreneurial skills during a prior spell of entrepreneurship are likely to intend to re-enter into entrepreneurship.

The first two hypotheses reflect the passive learning theory, while the third hypothesis reflects active learning theory.

\section{Measurement issues}

We have started with a representative panel of firms that registered as independent start-ups in 1994, 1998, 1999 and 2000 (on these panels see e.g. Bosma et al. 2004; Stam and Schutjens 2006). The firms that did not survive were traced within 1 year subsequent to the closure of the business, and a number of characteristics were recorded in a survey. At the end of 2004 we had placed telephone calls to all 510 exentrepreneurs from the panel that had closed their business in the previous decade. We succeeded in contacting 240 respondents, and collected information on several variables reflecting entrepreneurial experience, current occupation, and entrepreneurial preferences.

We thus have collected information from (at least) three points in time: the startup of the firm $\left(\mathrm{T}_{0}\right)$, the closure of the business $\left(\mathrm{T}_{1} ; 1\right.$ to 10 years after start-up) and a survey subsequent to firm exit $\left(\mathrm{T}_{2} ; 1\right.$ to 9 years after closure). If the firm survived more than 1 year, we have also gathered information each year between the start-up and the closure of the firm (the years between $T_{0}$ and $T_{1}$ ).

The non-response analysis revealed that there are no significant differences between the non-respondents and respondents, with the exception of age: respondents tend to be older than non-respondents, which suggests that renascent entrepreneurs (as these tend to be relatively young) were undersampled. This response bias can be attributed to the higher mobility of younger people, which makes it harder to trace them at a known address via telephone surveys. 
To measure whether an ex-entrepreneur has the (stated or revealed) preference to start a new firm again, a dependent variable has been constructed. The dependent variable reflects whether the respondents had no subsequent preference to (re-)enter into entrepreneurship (value 1: "one-off entrepreneurs": 103 cases, 42.9\%) or whether they indeed had a preference to (re)enter into entrepreneurship again (value 0: "renascent entrepreneurs": 137 cases, 57.1\%).

The independent variables influencing the decision to be a renascent entrepreneur can be categorized into four main groups, which reflect human capital, social capital, firm exit type, and demographic (control) variables.

The human capital of the ex-entrepreneurs is reflected by several different measures. Respondents were asked to indicate the highest level of education they had completed. This variable was coded as a nominal variable with low or medium level of education as 0 and high educational attainment as 1 . Two dummy variables are included which indicate whether the individual had industry experience prior to starting her firm and whether the ex-entrepreneur had started more than one firm as an indicator of prior entrepreneurial experience.

The measure of social capital reflects bonding social capital (Davidsson and Honig 2003). The indicator of bonding ties consists of a dummy taking on the value of one if the respondent knew family or friends running their own business.

Three variables are used to characterise the type of firm exit. The first variable indicates whether or not the prior firm was successfully sold (in total or parts). Firms which exit due to acquisition may be inferred to have been a success in that they exhibited (statistically significant) above average sales revenues and employment prior to exit. This variable also reflects the availability of financial capital, as it can be assumed that the sale of the firm frees financial resources for the ex-entrepreneur. In this sample 26 firm exits involved the sale of (parts of) the firm. Due to the low number of bankruptcies (only seven) ${ }^{5}$ we were, in fact, not able to use this measure of "firm failure". However, since six of the seven entrepreneurs with bankruptcy as the cause of firm exit responded that they still had entrepreneurial preferences, this variable seems to be highly relevant. A second indicator of firm exit reflects a low commitment to entrepreneurship, i.e. closure for non-business reasons. The dummy variable "exit due to personal circumstances" (like personal health or family situations) was used. The timing of the exit is reflected by a dummy variable which indicates a prior firm age of less than or equal to 3 years, i.e. a relatively early firm exit.

Three demographic characteristics are controlled for: gender (a dummy for male), age (a dummy for being 40 years or younger), and urban location (a dummy for being located in one of the four largest cities in the Netherlands: Amsterdam, Rotterdam, Utrecht or The Hague). These variables are included to control for demographic influences.

Finally, we have controlled for the opportunity structure during self-employment by taking into account the industry in which the prior firm was active. Three industry dummies are used, reflecting the industries with the fastest-growing number of

\footnotetext{
${ }^{5}$ This low number (compared to $10 \%$ of exits in the overall business population in the Netherlands; CBS 2005) can probably be attributed to the relatively short life span and small size of the firms in our sample, which lowers the likelihood of large debts and the subsequent need for a formal bankruptcy procedure.
} 
Table 1 Logistic regression models estimating abstinence from renascent entrepreneurship

\begin{tabular}{|c|c|c|c|c|c|c|}
\hline \multirow[t]{2}{*}{ Independent variable: } & \multicolumn{3}{|l|}{ Model 1} & \multicolumn{3}{|l|}{ Model 2} \\
\hline & B & & S.E. & $\mathrm{B}$ & & S.E. \\
\hline Constant & -1.596 & $* * *$ & 0.484 & -2.032 & *** & 0.550 \\
\hline \multicolumn{7}{|l|}{ Human capital } \\
\hline Educational level (high) & -0.795 & ** & 0.326 & -0.857 & ** & 0.344 \\
\hline Prior industry experience & -0.457 & & 0.304 & -0.399 & & 0.324 \\
\hline Prior entrepreneurial experience & -1.062 & ** & 0.481 & -1.036 & ** & 0.511 \\
\hline \multicolumn{7}{|l|}{ Social capital } \\
\hline Entrepreneurial role models & -0.440 & & 0.322 & -0.655 & * & 0.349 \\
\hline \multicolumn{7}{|l|}{ Nature firm exit } \\
\hline Sold (parts of) prior firm & & & & -1.190 & ** & 0.581 \\
\hline Exit due to personal circumstances & & & & 1.105 & *** & 0.379 \\
\hline Prior firm age ( $>3$ years $)$ & & & & 0.574 & & 0.364 \\
\hline \multicolumn{7}{|l|}{ Demographics } \\
\hline Gender (female) & 0.601 & * & 0.327 & 0.358 & & 0.357 \\
\hline Age $(>40$ years $)$ & 2.031 & $* * *$ & 0.438 & 2.342 & *** & 0.490 \\
\hline Urban location & 0.899 & & 0.573 & 1.115 & $*$ & 0.622 \\
\hline \multicolumn{7}{|l|}{ Industry } \\
\hline Business services & 0.292 & & 0.345 & 0.289 & & 0.367 \\
\hline Construction & 0.058 & & 0.538 & 0.066 & & 0.574 \\
\hline High-tech & 0.198 & & 0.398 & 0.128 & & 0.426 \\
\hline $\mathrm{N}$ & & 236 & & & 231 & \\
\hline Model $X^{2}$ & & 46.436 & & & 63.750 & \\
\hline Df & & 10 & & & 13 & \\
\hline -2 Log likelihood & & 275.814 & & & 251.160 & \\
\hline Nagelkerke $\mathrm{R}^{2}$ & & 0.240 & & & 0.324 & \\
\hline
\end{tabular}

$p<0.10 ; * * p<0.05 ; * * * p<0.01$

entrants in the Netherlands (business services and construction) and high-tech industries.

\section{Empirical results}

Entrepreneurial preferences in the post-exit period range from $64 \%$ directly subsequent to firm exit to $57 \%$ during the survey a few years after firm exit. ${ }^{6}$ These preferences are still considerably higher than the entrepreneurial intentions in the overall adult population in the Netherlands, which is only $37 \%$ (see Blanchflower et al. 2001).

Two binary logistic regressions are used to analyse the likelihood that an exentrepreneur has no subsequent entrepreneurial preferences: one with the 'usual suspects' from the nascent entrepreneurship literature, and one that also includes variables related to the nature of the firm exit. The logistic regression tests the probability of having entrepreneurial preferences or not. The results are shown in Table 1.

\footnotetext{
${ }^{6}$ These percentages are comparable with earlier research by Stokes and Blackburn (2002), who found that almost $70 \%$ of the business owners that had to close their business claimed that they were encouraged by their experience to continue as a business owner.
} 


\subsection{Human capital}

Human capital seems to be positively related to renascent entrepreneurship. All three variables have the expected negative coefficient on being a one-night stand entrepreneur. Prior entrepreneurial experience has the strongest effect, followed by the general human capital indicator. The effect of prior industry experience has the expected direction, but is not statistically significant.

\subsection{Social capital}

The social capital variable - having entrepreneurial role models - has the expected negative relationship with abstaining from renascent entrepreneurship in the second model. Ex-entrepreneurs with entrepreneurial families and/or friends seem to be more persistent in their preference for entrepreneurship and are not deterred by a negative entrepreneurial episode.

\subsection{Firm exit type}

Two of the three variables related to the type of firm exit have rather strong effects in the expected direction. The success of the prior firm is negatively related to abstaining from renascent entrepreneurship, while personal circumstances - as a reason of firm exit - are positively related to abstaining from renascent entrepreneurship. In contrast to the expectations, entrepreneurs whose prior firm has survived the valley of death are not more likely to be renascent entrepreneurs. One possible interpretation is provided by McGrath (1999), who suggested that entrepreneurs view their startups as a real option and thus are not deterred from entering into subsequent entrepreneurship by terminating previous businesses early on.

\subsection{Demographics}

The strongest variable explaining renascent entrepreneurship is provided by the age variable - younger ex-entrepreneurs are much more likely to be renascent entrepreneurs than are older ex-entrepreneurs. However, since age is a proxy for other - yet unknown - underlying variables, this does not provide much insight by itself. If age makes such a large difference, how does the explanation differ for older ex-entrepreneurs in comparison with younger ex-entrepreneurs? A regression was estimated on the subpopulation of older ex-entrepreneurs, which yielded largely the same result as the regression for the entire population, with one remarkable exception. Entrepreneurial preferences of older ex-entrepreneurs are not affected by entrepreneurial role models, but rather by prior industry experience. They seem to be less affected by entrepreneurial role models and more shaped by their industry experience (which of course is at best meager for younger ex-entrepreneurs). Perhaps industry veterans are more likely to maintain entrepreneurial preferences, due to a lack of other career opportunities.

The other demographic variable, gender, has no significant effect on abstaining from renascent entrepreneurship (when the nature of the firm exit is included in the 
regression). An urban location (with relatively high levels of nascent entrepreneurship in general) has an unexpected effect: ex-entrepreneurs living in large cities are less likely to have entrepreneurial preferences.

\subsection{Industry}

We controlled for the opportunity structure during self-employment by taking into account the industry in which the prior firm was active. None of the three industry dummies that reflected relatively abundant opportunity structures (business services, construction, and high-tech industries) has a substantial effect on the preferences to reenter. We also did a robustness check comparing models with and without the industry dummies, but this did not change the effects of the other variables at all. Inclusion of the industry dummies hardly improved the explained variance of the models.

In order to test for the robustness of our results, we also estimated a regression, distinguishing respondents with and without a revealed preference for re-entry. This latter robustness check shows that there are few differences between the stated and revealed preference models, with one exception: educational level does not have an effect on the revealed preference to start a new business again. This latter outcome can be interpreted as follows: highly-educated ex-entrepreneurs keep the entrepreneurship option, but are not more likely to execute this option in face of other wellpaid wage earner options.

\section{Discussion and conclusions}

While a focus on renascent entrepreneurship is new and relatively unexplored, a large literature exists concerning nascent entrepreneurship. Do the factors conducive to nascent entrepreneurship affect renascent entrepreneurship in the same way?

Based on the empirical evidence presented here, the answer appears to be yes with some interesting nuances. Largely, the factors conducive to nascent entrepreneurship have a similar impact on renascent entrepreneurship (cf. Wagner 2003). There seems to be some type of sorting mechanism - those individuals endowed with characteristics that are typically not associated with nascent entrepreneurship are less likely to have the preference to start again subsequent to terminating the initial business. This mechanism essentially provides the learning referred to by the Jovanovic model: those entrepreneurs selected out of entrepreneurship have apparently learned that they are not favorably endowed with characteristics reflecting entrepreneurial talent. Indeed, almost $43 \%$ of the ex-entrepreneurs confirm the hypothesis of abstinence from entrepreneurship. As a result of learning about their underlying, but invisible (meager) endowment of entrepreneurial talent, these exentrepreneurs do not make the same mistake twice. In that sense, compared to novice entrepreneurs, experienced ex-entrepreneurs have gone through the filtering process that novice entrepreneurs have not yet been subjected to. This confirms hypothesis 1 . But perhaps this is a bit too deterministic. Individuals that have once entered into entrepreneurship might have two important advantages in contrast to de novo nascent entrepreneurs. First, when they have successfully sold their prior firm their access to financial resources increases (hypothesis 2), and second, they have 
accumulated entrepreneurial experience which increases the probability of having acquired entrepreneurial skills (and as a consequence a higher $\mathrm{P}^{*}$ : hypothesis 3 ). These two advantages make them more likely to intend to start again, which is reflected in the positive effects of having sold the prior firm and of (entrepreneurship specific) human capital.

This study has challenged the view of entrepreneurial learning posited in Jovanovic's (1982) model and suggested that instead, in addition to learning about the underlying endowment of entrepreneurial skills (cf. passive learning), episodes of entrepreneurship can also augment that endowment of entrepreneurial talent (cf. active learning). This explains why a considerable group of ex-entrepreneurs would choose to become renascent entrepreneurs. The findings of this paper suggest that the ability of ex-entrepreneurs to learn from their entrepreneurial experience is not homogenous. Rather it is shaped by characteristics that also promote nascent entrepreneurship in general (human capital and entrepreneurship-specific social capital). The nature of the firm exit also affects the entrepreneurial preferences subsequent to firm exit: a positive effect of the sale of a successful firm, and a negative effect of exit due to personal circumstances.

This study shows the added value of a longitudinal research design, in which not only the experience of the entrepreneur but also the performance of the prior firm is taken into account. Both issues are important in the explanation of renascent entrepreneurship. As public policy increasingly focuses on promoting entrepreneurship to generate employment, growth and global competitiveness, it is important to recognize that renascent entrepreneurs provide not just an important source of entrepreneurship, but also a source with entrepreneurial skills that may be enhanced compared to those of novice entrepreneurs. Both failed firms and successful ones show useful learning effects and path dependencies in the careers of serial entrepreneurs (cf. Sarasvathy and Menon 2006). Future research may reveal what distinguishes renascent entrepreneurs that have improved their entrepreneurial skills, and those that did not, and that are perhaps better characterized as 'habitual failures'.

In order to increase entrepreneurial activity in society, government policies and programmes should aim at increasing individual awareness of the possibilities of entrepreneurial careers, as well as providing individuals with entrepreneurial experience. One way to realize this is to stimulate individuals to make the transition into entrepreneurship (once) early in their life. This will lead to a substantial increase in the potential supply of entrepreneurs, as individuals who have been an active entrepreneur once are more likely to prefer entrepreneurship once again than individuals that stay within the 'employee' status (cf. Ronstadt 1986).

Open Access This article is distributed under the terms of the Creative Commons Attribution Noncommercial License which permits any noncommercial use, distribution, and reproduction in any medium, provided the original author(s) and source are credited.

\section{References}

Arenius P, De Clercq D (2005) A network-based approach on opportunity recognition. Small Bus Econ 24:249-265

Audretsch DB, Keilbach M, Lehmann E (2006) Entrepreneurship and economic growth. Oxford University Press, New York 
Bates T (2005) Analysis of young, small firms that have closed: delineating successful from unsuccessful closures. J Bus Venturing 20:343-358

Blanchflower D, Oswald A (1998) What makes an entrepreneur? J Labor Econ 16:26-60

Blanchflower DG, Oswald A, Stutzer A (2001) Latent entrepreneurship across nations. Eur Econ Rev 45:680-691

Bosma N, Van Praag M, Thurik R, De Wit G (2004) The value of human and social capital investments for the business performance of startups. Small Bus Econ 23:227-236

Bruce D, Schuetze HJ (2004) The labor market consequences of experience in self-employment. Labour Econ 11(5):575-598

CBS (2005) Faillissementen: Oorzaken en schulden in 2004. Centraal Bureau voor de Statistiek, Voorburg/Heerlen

Davidsson P (2006) Nascent entrepreneurship: empirical studies and developments. Found Trends Entrep 2:1-76

Davidsson P, Honig B (2003) the role of social and human capital among nascent entrepreneurs. J Bus Venturing 18:301-331

Diochon M, Gasse Y, Menzies T, Garand D (2002) Attitudes and entrepreneurial action: exploring the link. Paper for ASAC 2002. Winnipeg, Manitoba

Ericson R, Pakes A (1995) Markov-perfect industry dynamics: a framework for empirical work. Rev Econ Stud 62:53-82

European Commission (2002) Bankruptcy and a fresh start: stigma on failure and legal consequences of bankruptcy. DG Enterprise, Brussels

Evans D, Jovanovic B (1989) An estimated model of entrepreneurial choice under liquidity constraints. J Polit Econ 97:808-827

Evans D, Leighton L (1989) Some empirical aspects of entrepreneurship. Am Econ Rev 79:519-535

Forbes DP (2005) Are some entrepreneurs more overconfident than others? J Bus Venturing 20:623-640

Headd B (2003) Redefining business success: distinguishing between closure and failure. Small Bus Econ 21:51-61

Holmes TJ, Schmitz JA (1990) A theory of entrepreneurship and its application to the study of business transfers. J Polit Econ 98:265-294

Jacobs J (1961) The death and life of great American cities. Vintage Books, New York

Jovanovic B (1982) Selection and the evolution of industry. Econometrica 50:649-670

Jovanovic B (1994) Firm formation with heterogeneous management and labor skills. Small Bus Econ 6:185-192

Kim PH, Aldrich HE, Keister LA (2006) Access (not) denied: the impact of financial, human, and cultural capital on entrepreneurial entry in the United States. Small Bus Econ 27:5-22

Klepper S (2002) The capabilities of new firms and the evolution of the US automobile industry. Ind Corp Change 11:645-666

Knight FH (1921) Risk, uncertainty and profit. Houghton Mifflin, New York

Kolvereid L, Isaksen E (2006) New business start-up and subsequent entry into self-employment. J Bus Venturing 21:866-885

Lazear EP (2004) Balanced skills and entrepreneurship. Am Econ Rev 94:208-211

Lévesque M, Minniti M (2006) The effect of aging on entrepreneurial behavior. J Bus Venturing 21:177194

Lippman SS, Rumelt RP (1982) Uncertain imitability: an analysis of interfirm differences in efficiency under competition. Bell J Econ 13:441-438

McGrath RG (1999) Falling forward: real options reasoning and entrepreneurial failure. Acad Manage Rev 24:13-30

Parker S (1996) A time series model of self-employment under uncertainty. Economica 63:459-475

Parker S (2004) The economics of self-employment and entrepreneurship. Cambridge University Press, Cambridge

Parker S (2005) The economics of entrepreneurship. Found Trends Entrep 1:1-55

Phillips DJ (2002) A genealogical approach to organizational life chances: the parent-progeny transfer among Silicon Valley Law firms, 1946-1996. Adm Sci Q 47.3:474-506

Reynolds PD, Carter NM, Gartner WB, Greene PG (2004) The prevalence of nascent entrepreneurs in the United States: evidence from the panel study of entrepreneurial dynamics. Small Bus Econ 23:263-284

Ronstadt R (1986) Exit, stage left why entrepreneurs end their entrepreneurial careers before retirement. J Bus Venturing 1(3):323-338

Ronstadt R (1988) The corridor principle. J Bus Venturing 3:31-40 
Sarasvathy S, Menon A (2006) Failing firms and successful entrepreneurs: serial entrepreneurship as a temporal portfolio.Paper for the workshop on Firm Exit and Serial Entrepreneurship, Max Planck Institute of Economics, Jena, 13-14 January 2006

Stam E, Schutjens V (2006) The fragile success of team start-ups. In: Oakey R, During W, Kauser S (Eds) New technology-based firms in the new millenium. Vol. V. Elsevier Science, Oxford. pp. 219-233

Stokes D, Blackburn R (2002) Learning the hard way: the lessons of owner-managers who have closed their businesses. J Small Bus Enter Dev 9:17-27

Tamasy C (2006) Determinants of regional entrepreneurship dynamics in contemporary Germany: A conceptual and empirical analysis. Reg Stud 40(4):365-384

Thornhill S, Amit R (2003) Learning about failure: Bankruptcy, firm age and the resource-based view. Organ Sci 14:497-509

Van der Klauw B (1998) De effecten van het beëindigen van een onderneming op toekomstig ondernemerschap. Working Paper, Vakgroep Algemene Economie, Vrije Universiteit, Amsterdam

Van Gelderen MW (1999) Ontluikend ondernemerschap. EIM, Zoetermeer

Van Praag CM (2003) Business survival and success of young small business owners. Small Bus Econ 21:1-17

Wagner J (2003) Taking a second chance: Entrepreneurial re-starters in Germany. Appl Econ Q 49:255272

Wagner J (2005) Nascent and infant entrepreneurs in Germany. Evidence from the Regional Entrepreneurship Monitor (REM). University of Lueneburg Working Paper Series in Economics, No. 1

Wagner J, Sternberg R (2004) Start-up activities, individual characteristics, and the regional milieu: Lessons for entrepreneurship support policies from German micro data. Ann Reg Sci 38:219-240

Wright M, Robbie K, Ennew C (1997) Serial entrepreneurs. Br J Manage 8:251-268 